INTERNATIONAL JOURNAL OF MULTIDisciplinARY RESEARCH AND ANALYSis

ISSN(print): 2643-9840, ISSN(online): 2643-9875

Volume 04 Issue 07 July 2021

DOI: 10.47191/ijmra/v4-i7-02, Impact Factor: 6.072

Page No.- $863-868$

\title{
Yard Biodiversity to Support Local Economic Development in Skouw Mabo Village, Muara Tami Sub District, Jayapura City, Papua Province, Indonesia
}

\author{
Alfred Alfonso Antoh ${ }^{1}$, Leonardo Elisa Aisoi ${ }^{2}$ \\ 1,2 Biology education study program, Department of Mathematics and Natural Sciences Education, Faculty of Teacher Training and \\ Education, Cenderawasih University, Abepura 99351, Jayapura, Papua Province, Indonesia
}

\begin{abstract}
The biodiversity of plants in the tropical forests of Papua is the time to be conserved using the yard approach. These plants have ecological benefits for environmental sustainability but also as wildlife habitat. The plants that are planted around community homes now also have an economic impact on the family to improve the family's economy. This study aims to obtain the value of yard biodiversity based on vertical diversity (strata) and functional diversity (horizontal) and to determine its benefits. Data collection using vegetation analysis methods and calculation of biodiversity values using the Shanon and Wiener indices. The results of the study are that there are 2 very dominant types of plants in the yard, namely areca nut (Areca catechu $L$.) with a summed dominance ratio (SDR) of 58.4-66.2. For other types there are Moringa (Moringa oleifera) with (SDR) 10.8. The conclusion of the dominant areca nut and moringa is closely related to culture and the two plants currently support economically for increasing the income of families in the village.
\end{abstract}

KEYWORDS: Productive yards, Vertical diversity, Horizontal diversity, Farmer's income

\section{INTRODUCTION}

Changes in the environment affect various aspects of life. Changes that occur in the human environment cause disruption to the balance because some of the environmental components become less functional. Environmental changes can occur due to human intervention and can also be due to natural factors (Helena et al. 2018). Forest and land change is currently motivated by high demand for consumption for food, clothing and shelter needs. The need for agricultural businesses and settlements from time to time continues to increase followed by a high increase in population growth (Keraf 2010). Another thing that has been investigated is that agricultural diversification is very dependent on the demographic characteristics of the population and is related to the level of income of the people (Kujawska et al. 2018). Clearing forests and land for food is always inadequate because it is more oriented to food production. The type of land also determines suitable agricultural products to be developed (Zahri 2018). On the other hand, the current food production does not have to be obtained from large tracts of land, but can be functioned in small areas to produce food so that it can meet human needs at this time. Narrow land use is managed by growing economic crops that have high production value.

Utilization of house yards with economic value plants is being developed in urban areas that are starting to become densely populated. In urban areas land use modifications have been made to maximize their functions and benefits. This is different from the condition of the yard in the village. In the village yard is very broad but the types of plants planted are still lacking in a variety of functions and benefits. Traditional use of the yard can increase biodiversity and expand the functioning of the ecosystem as well as being economically and socially able to increase its function (Mohri et al. 2013). Utilization of the yard with agroforestry techniques can be developed in the village. Agroforestry techniques can increase farm household income (Linger 2014). Utilization of the yard is good with the type of plant based on its height (vertical diversity) but also the utilization of plants with their functions (horizontal diversity).

\section{MATERIAL AND METHOD}

The yard data was collected with a sample of 20 yards in Skouw Mabo village, Muara Tami District, Jayapura City, Papua Province, Indonesia (fig 1). Data was collected for approximately one month with tools and materials such as: meter roll, 
Yard Biodiversity to Support Local Economic Development in Skouw Mabo Village, Muara Tami Sub District, Jayapura City, Papua Province, Indonesia

questionnaire, global positioning system (GPS), camera and voice recorder. Data on community yards in the village of Skouw Mabo studied horizontal (structural) and / or horizontal (functional) diversity.

Measurement of vertical diversity was carried out around the sample villages (front, side and back yards). In addition to the average yard area data in Skouw Mabo village, there is also another uniqueness in this study, namely: the vertical diversity of the yard plants. Each sample household also showed different plant diversity for each type of plant in their yard. The diversity of vertical yards is meant by the form of diversity based on the stratification of plants (height) planted by the community around their yard. Then an analysis of vegetation per yard unit was carried out. Grouping plants into 5 strata, namely: strata V is a tree> $10 \mathrm{~m}$ tall; strata IV ie small trees or large shrubs 5-10 m, strata III are small shrubs, shrubs 2-5 m strata II are shrubs and strata I are herbs, grass <1 m (Arifin et al. 1997).

Data collection methods that will be implemented in this research are survey, interview and literature study methods. The survey method with a random purposive technique was performed by direct observation to the community yard.

Yard data analysis method is a yard vegetation analysis method by first identifying the species and family of the plant. Next measure the yard area (number of individuals, families, strata, functions or uses and location found) (Arifin et al.2012). Agricultural biodiversity in the yard (Fachrul 2007):

a. Density $\quad=\frac{\sum \text { wholeplants }}{\Sigma \text { whole sampling units }}$

b. $\%$ Relative density $=\frac{\sum \text { individuals of species }}{\sum \text { individual of all species }} x 100 \%$

c. Frequency $=\frac{\sum \text { sampling unit of species }}{\sum \text { whole sampling unit }}$

d. $\%$ Relative frequency $=\frac{\sum \text { frequency of species }}{\sum \text { frequency value for all species }} \times 100 \%$.

e. Dominance $\quad=\frac{\sum \text { basal area of species }}{\sum \text { whole basalt }}$

f. \% Dominance $\quad=\frac{\sum \text { basal area of species }}{\sum \text { basal cover all types }} \times 100 \%$

$I N P=K R+F R+D R$

$\mathrm{FR}=$ relative frequency

$\mathrm{KR}=$ Relative density

$\mathrm{DR}=$ Relative dominance

INP = important value index

g. $\mathrm{SDR}=\frac{\mathrm{INP}}{3} \times 100 \%$

SDR: Summed dominance ratio (Fachrul. 2007)

h. $H^{\prime}=\sum_{i: 1}^{S} p i \ln (p i)$

Information:

$\mathrm{H}^{\prime}=$ Shannon-Wienerbiodiversity index $\quad$ (Fachrul 2007):

$\mathrm{Pi}=\mathrm{ni} / \mathrm{n}$-type individuals $\mathrm{H}^{\prime}>3 \mathrm{H}^{\prime} 1 \mathrm{~S}^{\prime}$ High abundant species diversity $\leq 3$ Moderat abundant species diversity ni= number

of $\mathrm{i}$

$\mathrm{n}=$ Number of individuals $\quad \mathrm{H}^{\prime}<1$ Biodiversity of species is abundant slightly

In = Logaritme natural

$\mathrm{s}=$ Number of individuals

\section{RESULT AND DISCUSSION}

The results of research on the biodiversity of the yard there are 77 types of garden plants in the village of Skouw Mabo, Jayapura City, Papua Province, Indonesia. The data taken came from 3 RTs (RT: Neighborhood Association ) (Fig 1). Each 
Yard Biodiversity to Support Local Economic Development in Skouw Mabo Village, Muara Tami Sub District, Jayapura City, Papua Province, Indonesia

household has different yard characteristics both types and number of plants developed. The results of this study are more limited in discussing the types of plants that are predominantly found in the yard of the village community. Other research states that the predominance of dominant plants can be interpreted as plants that have economic but also socio-cultural interrelations

(Pereira 2019).

The types obtained in the field are 2 types that are dominant in the community yard (Table 1). This species was found dominantly in the community yard and functioned and utilized by the community in Skouw Mabo village.

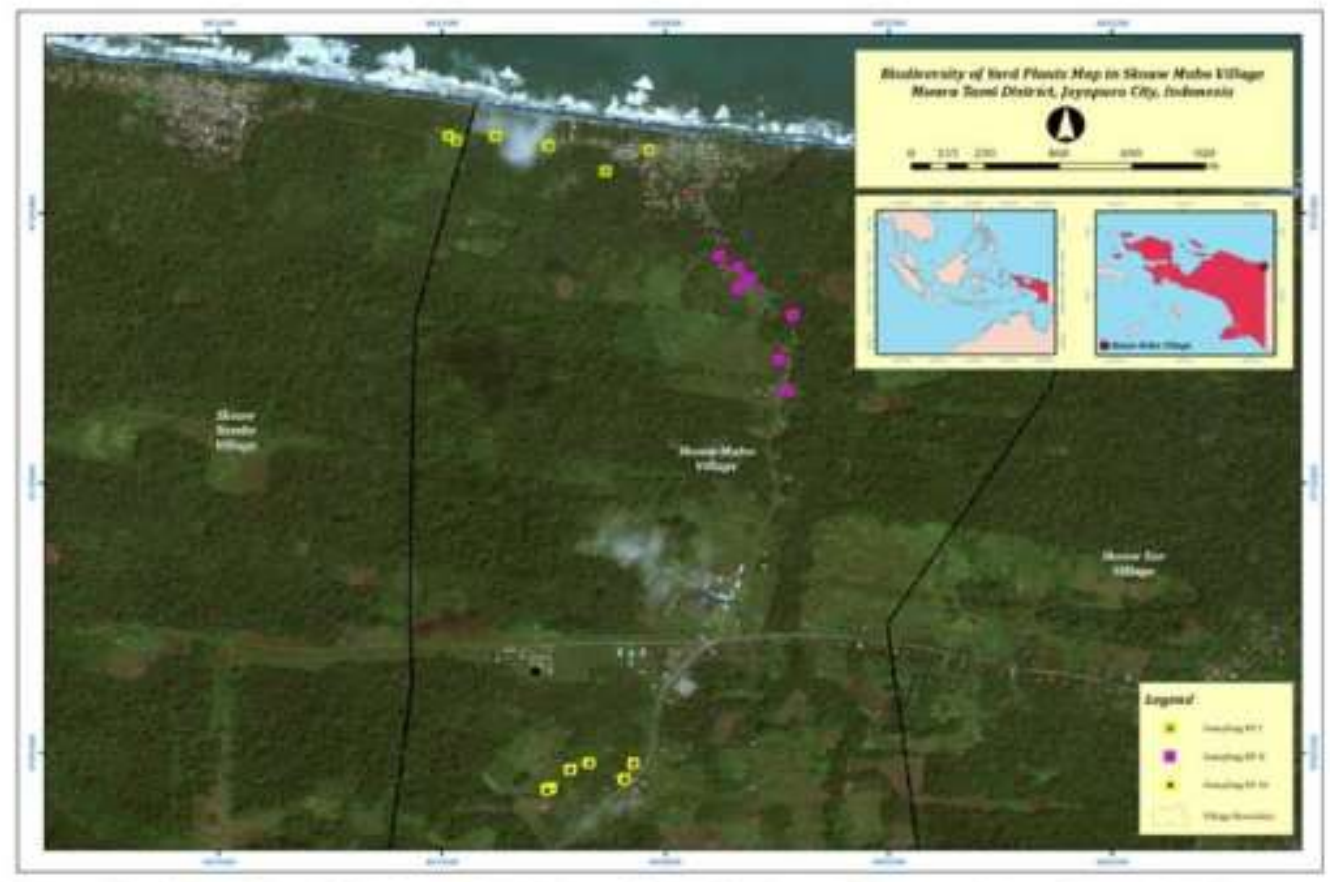

Figure 1. Citra Map (RT1,2 and 3) Skouw Mabo Village, Jayapura City, Papua Province, Indonesia

Table 1. Dominant plant species in Kampung Skouw Mabo, Muara Tami District, Jayapura City, Papua Province, Indonesia

\begin{tabular}{|c|c|c|c|c|c|c|c|c|c|}
\hline $\begin{array}{l}\text { RT } \\
\text { Location }\end{array}$ & $\begin{array}{l}\text { Averag } \\
\text { e area } \\
\left(\mathrm{m}^{2}\right)\end{array}$ & INP & $\mathbf{H}^{\prime}$ & $\overline{\text { SDR }}$ & Plants & $\begin{array}{l}\text { Dominat } \\
\text { species }\end{array}$ & Family & Level & Fungtion \\
\hline 1 & 4741,9 & 69,2 & 1,4 & 66,2 & Betel nut & $\begin{array}{l}\text { Areca catechu } \\
\text { L. }\end{array}$ & Arecaceae & V & $\begin{array}{l}\text { The fruit is } \\
\text { eaten }\end{array}$ \\
\hline 2 & 2320,5 & 60,8 & 1,7 & 58,4 & Betel nut & $\begin{array}{l}\text { Areca catechu } \\
\text { L. }\end{array}$ & Arecaceae & V & $\begin{array}{l}\text { The fruit is } \\
\text { eaten }\end{array}$ \\
\hline 3 & 2860,9 & 13,8 & 2,1 & 10,8 & Moringa & $\begin{array}{l}\text { Moringa } \\
\text { oleifera }\end{array}$ & $\begin{array}{l}\text { Moringace } \\
\text { ae }\end{array}$ & IV & $\begin{array}{l}\text { Vegetables } \\
\text { and } \\
\text { medicinal } \\
\text { plants }\end{array}$ \\
\hline
\end{tabular}

Information: RT: Neighborhood Association

The extent and diversity of dominant garden species

The average area of yards in Skouw Mabo Village is $3307.8 \mathrm{~m} 2$ with the number of plants found, which are 77 types of plants of herbaceous, seedlings, shrubs, small trees and large trees. The size of a yard is very influential in its management for farm households (Guuroh 2014). The area of the yard is dominated by Pinang in RT 1 and 2. RT 1 and RT2 are inhabited by indigenous tribes (Skouw tribe). Whereas for RT 3 there are many migrants, namely Butonese, Buginese, Makassarese and Javanese. Plant species found dominantly in the RT are Moringa plants.

Areca nut is found in the community yard of the summed dominance ratio (SDR) of 66.2 in RT 1. For RT 2 the value of SDR is $\mathbf{5 8 . 4}$ which means that it is quite large. The people of Skouw Mabo village plant areca nut in their yard (fig a\&b). Areca nut has a cultural value but is currently an economic and high-value commodity. The demand value of areca nuts is quite high 
Yard Biodiversity to Support Local Economic Development in Skouw Mabo Village, Muara Tami Sub District, Jayapura City, Papua Province, Indonesia

in the market, this is evidenced by the price of a single areca nut ranging from Rp.50,000-500,000. The rise and fall of the price of areca nuts in the market is largely determined by the rainy season and summer. When it is summer, the small amount of areca nut produced causes the price to rise to $\mathrm{Rp} .500,000$. This is inversely proportional if in the rainy season, the production of areca nut will be excessive so that it can cause the price to only around Rp.50,000 in the market. Plant diversity in the yard is important to maintain income stability (Kujawka 2018). The income earned is also determined by the size of the family member (Dirimanova 2018). Utilization of village funds to develop other plant products to help the community when their income is not optimal. Other studies reveal that budget allocation policy is the second priority in agricultural policy in rural areas in Romania (Galluso 2017). Furthermore, in other studies also explained that the economic conditions of farm households can be developed with policies to provide reinforcement to them (Hendrarini 2018). Other research also states that farm households in the coastal areas of Papua are highly dependent on agricultural products sold to the market (Antoh et al. 2018).

(a)

(b)

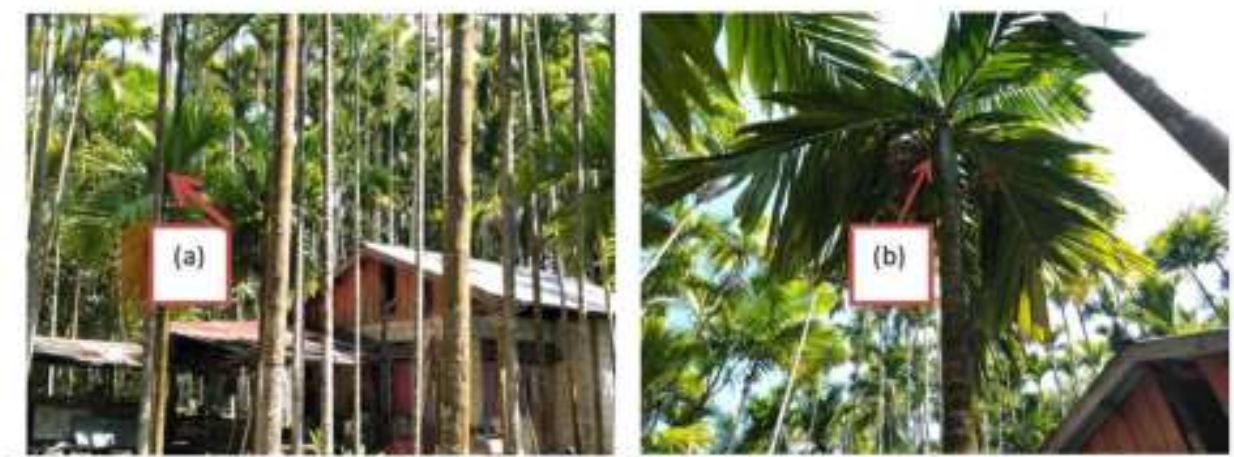

Figure 2. Areca catechu L.(a\&b) in the yard of Skouw Mabo villagers, Jayapura City, Papua Province, Indonesia

Moringa is a type of introduction plant that goes to Skouw Mabo following the community's presence. Moringa is included in the type of large tree with a morphological form of woody plants and has many functions for the majority Butonese in RT3 (Fig c). Other studies suggest that the composition and structure of plants in the yard need to be considered in terms of their function and use (Ogwu 2014). Moringa plants can function as a vegetable but are also used as medicinal plants. Summed dominance ratio (SDR) value is calculated with a value of 10.8 . This means that this plant is almost always found in community yards.

(c)

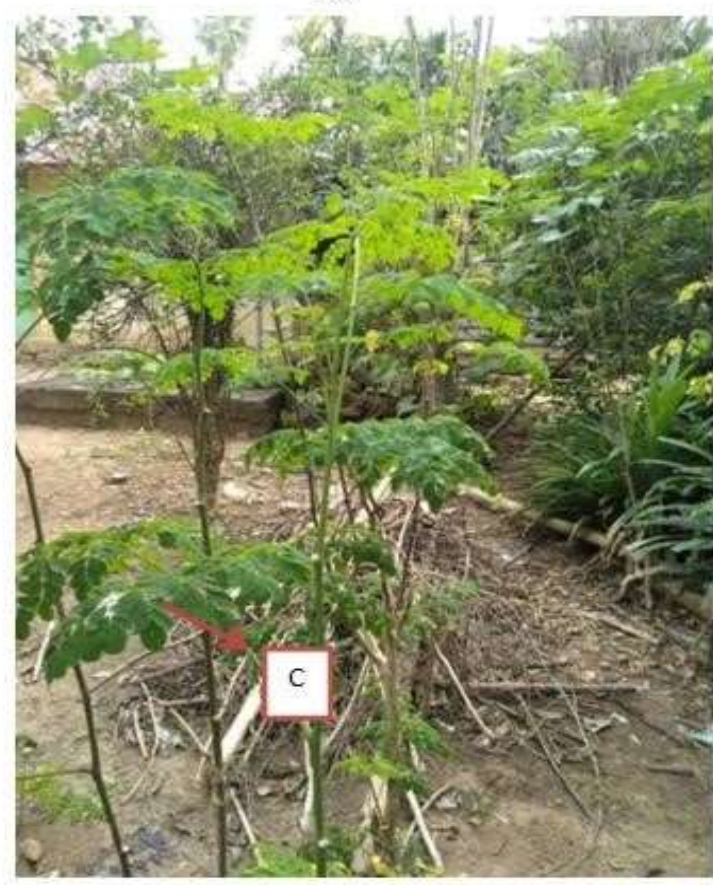

Figure 3. Moringa oleifera (c) found in the yard of the Buton community, in the village of Skouw Mabo, Jayapura City, Papua Province, Indonesia 


\section{Yard Biodiversity to Support Local Economic Development in Skouw Mabo Village, Muara Tami Sub District, Jayapura City, Papua Province, Indonesia}

\section{Yard Biodiversity}

The calculation value of the work biodiversity is measured by the Shannon Winner index. Calculation of yard biodiversity value for areca nut plants (1.4-1.7). This means that yard biodiversity is of moderate value in RT1 and RT 2. Whereas for RT 3 the value of biodiversity is 2.1. This means that biodiversity for the yard in RT3 is also of medium value with the dominant plant species being Moringa. This is in line with studies that have been conducted previously that generally the yards of coastal villages in Papua have moderate biodiversity values (Antoh et al. 2019). Coastal yards in Papua also differ from those in mountainous areas which are more dominated by cassava and sweet potato species (Antoh and Raunsay 2019).

Moringa plant is a type of introduced species imported from outside Papua and developed by the Buton tribe. Other studies have also been conducted to observe introductory species in Romania and compare with local species (Farenti 2015). Moringa plants are brought and planted in the yard of the houses of the Buton people and also they plant other plants around their yard such as: fruits, vegetables, herbs, and plants with other functions. Other studies compare the diversity of garden plants in Bangladesh where vegetables and fruit are quite dominant plants developed in the yard (Ogwu et al. 2014).

\section{CONCLUSIONS}

Dominant plants planted in the yard have economic and cultural values so that they are dominantly found in the community yard. Both types of plants are very beneficial for improving the family economy.

\section{ACKNOWLEDEMENTS}

Our gratitude goes to Biology Education Study Program, Department of Mathematics and Natural Sciences, Faculty of Teacher Training and Education, Cenderawasih University for research funding through faculty PNBP with contract number 1306 A / UN20.1.1 / LT / 2019.

\section{LITERATURE CITED}

1) Antoh A., Raunsay EK. 2019. Diversity of Yard Plants in the Buffer Zone of the Cycloop Nature Reserve, Jayapura City, Papua Province, Indonesia. AAB Bioflux; 11 (3):157-161.

2) Antoh A., Nurhayati., Chozin M. A., Arifin H. S. 2019. Short communication: Agricultural biodiversity and economic productivity of the yards in Arguni Bawah, Kaimana District, West Papua Province, Indonesia. 20 (4): 1020-1026.

3) Antoh. A., Nurhayati., Chozin MA, Arifin HS. 2018. Penilaian keberlanjutan masyarakat di Distrik Arguni Bawah, Kabupaten Kaimana, Provinsi Papua Barat. Jurnal Ilmu Lingkungan. 16 (2): 113-119.

4) Arifin HS., Sakamoto K., Chiba K.1997. Effects of the Fragmentation and the Change of the Social and Economic Aspects on the Vegetation Structure in the Rural Home gardens of West Java, Indonesia. Journal of Japan Institute of Landscape Architecture. 60 (5): 489-494.

5) Arifin HS, Munandar A, Schultink G, Kaswanto RL 2012. The role and impacts of small-scale, homestead agro-forestry system" pekarangan" on houshold prosperity: an analysis of agro-ecological zones of Java, Indonesia. International Journal of AgriScience. 2(10): 869-914.

6) Dirimanova V2018. The Role of the Extension Services for the Develeopment of the Small-Scale Farms in Bulgaria. Bulgarian Journal of Agricultural Science.18; 24 (1):35-39.

7) Fachrul MF. 2007. Metode Sampling Bioekologi. Jakarta (ID): Penerbit Bumi Aksara: Jakarta.

8) Farenti S., Maria L., Alexandra M.2015. Teresterial Isopods from Salonta Town, Western Romania. South Western Journal of Horticulture, Biology and Environment. 6 (1): 21-31.

9) Galluso N. 2017. The Common Agricultural Policy and Employment Opportunities in Rumanian Rural Areas: The Role of Agritourism. Bulgarian Journal of Agricultural Science. 23: 14-21.

10) Guuroh RT., Uibrig H., Acheampong E.2014. How does homeggarden size affect input and output per unit area?-a case study of the Bieha District, Southern Burkina Faso. International Journal of Agriscience. 4 (3): 196-208.

11) Helena., Nery A., Pinto., Joseph EH., Peter N., Rafael FB., Carlos AP. 2018. Economic Impacts of Payments for Environmental Services on Livelihoods of Agro-Extractivist Communities in the Brazilian Amazon. Ecological Economics. 152: 378-388.

12) Hendrarini H., Rifan JS., Teguh S., Eko N., Kusnandar., Endang SR. 2018. The Effect of Charity Attitude and Economic Condition on the Farmers' Houshold Food Security. Bulgarian Journal of Agricultural Science.24 (2):206-212.

13) Keraf AS. 2010. Etika Lingkungan Hidup. Jakarta (ID): Penerbit Kompas:Jakarta; 
Yard Biodiversity to Support Local Economic Development in Skouw Mabo Village, Muara Tami Sub District, Jayapura City, Papua Province, Indonesia

14) Kujawska AK., Danuta Z., Agnieszka SR. 2018. The Probability of Farm's DiversificationOn The Example of Central Pomerania in Poland. Bulgarian Journal of Agricultural Science. 24 (2):171-179.

15) Linger E. 2014. Agro-ecosystem and socio-economic role of homegarden agroforestry in Jabithenan District, NortWestern Ethiopia: implication for climate change adaptation.Springer Open Journal. 3: 1-9

16) Mohri H., Shruti L., Osamu S., Anparasan M., Nimal G, Irham, Hoang VT, Gamni H., Kazuhiko T., Srikantha H. 2013. Assessment of Ecosystem services in Homegardens Systems in Indonesia, Sri Lanka, and Vietnam. Ecosystem Services. 5:124-136.

17) Ogwu MC., Osawaru ME., Chime AO. 2014. Comparative Assessment of Plant Diversity and Utilization Patterns of Tropical Home Gardens in Edo State, Nigeria. Scientia Africana.13 (2):46-162.

18) Pareira GVM., Dão PCN., Antonio IMJ., Zulma SV., Adriane BPM., Luciana PSV., Carlos RS. 2019. Exploring the Impacts of Posthavest Processing on the Aroma Formation Coffee Beans- A review. Food Chemistry. 272: 441-452.

19) Zahri I, Dessy A., Elisa W., Sabaruddin., Umar MH. 2018. Comparing Rice Farming Apperance of Different Agroecosystem in South Sumatera, Indonesia. Bulgarian Journal of Agricultural Science. 24 (2):189-198. 